ally, but it is not impossible, as Mukai was the first to show 30 years ago ${ }^{6}$. Such experiments have yielded $\mu$ of about 1 or higher $^{7}$, but more data are necessary.

The rates of molecular evolution of neutral sequences, as well as direct data ${ }^{8}$, show that in mammals the mutation rate per nucleotide per generation is about $10^{-8}$, which implies some 100 mutations per diploid genome. Of course, this gives only an upper estimate of $\mu$, because only a fraction of all mutations are deleterious. At the moment, we cannot rule out any value of that fraction between under 1 per cent and over 50 per cent.

It is time to realize that the controversy about the factors involved in the evolution of sex and several other phenomena will not be resolved by theoretical arguments. It is clear what data are necessary, and experimentalists should not pass a unique opportunity to make 19 hypotheses obsolete at a single stroke.

Alexey S. Kondrashov is in the Section of Ecology and Systematics, Cornell University, Ithaca, New York 14853, USA.

\title{
-SPELEOLOGY
}

\section{Creatures from the black lagoon}

If laboratory work sometimes seems claustrophobic, pity the diver below, almost submerged in the sulphurous waters of Movile cave in southeastern Romania. The cave has no natural entrance and lies under a thick cover of wind-blown silt; it was discovered only in 1986 , when it was broken into by shaft construction, and its former isolation is indicated by the lack of the radioactivity from the Chernobyl nuclear disaster that is usually present in Romanian caves. This way, researchers gained access to a unique ecosystem which has been isolated from the surface for millions of years.

Despite the absence of sunlight, the cave supports a rich invertebrate community. Fortyseven species of cave-adapted invertebrates have been discovered there, 31 of which are unknown elsewhere. The basis for the ecosystem appears to be sulphur-metabolizing bacteria, which synthesize organic matter using energy obtained from the oxidation of hydrogen sulphide - the cave con. tains white tufts of a fungal bacterial mat, especially in rooms enterable only through a subterranean lake. The food chain starts with $\mathrm{H}_{2} \mathrm{~S}$ and $\mathrm{CO}_{2}$, with the resulting acids buffered by the limestone bedrock. These chemoautotrophic bacteria in turn feed other bacteria and fungi that support the cave animals.

Depending on whether they live in anaerobic (water-filled) or aerobic (airfilled) limestone cavities, 'sulphur bac. teria' can metabolize sulphur in one of three different ways: oxidize $\mathrm{H}_{2} \mathrm{~S}$ to sulphuric acid, as in Movile; reduce sulphates to $\mathrm{H}_{2} \mathrm{~S}$ using energy from external organic matter; or oxidize $\mathrm{H}_{2} \mathrm{~S}$ to native sulphur.

The study of these bugs is of more than just academic interest, as was amply proved by the conference ${ }^{*}$ at which the descriptions of life in Movile cave were a highlight (S. M. Sarbu and T. Kane, Univ. of Cincinnati). Sulphide-oxidizing bacter-

* Breakthroughs in Karst Geomicrobiology and Redox Geochemistry. University of Colorado at Colorado Springs. 16-19 February 1994 ia such as Thiotrix in well water from limestone aquifers can clog irrigation pipes (R. Brigmon, Univ. of Florida; $\mathbf{H}$. Martin, Univ. of Georgia). And their sulphate-reducing counterparts can foul platinum electrodes that are used to evaluate the oxidation potential of

swampy green colour and contained catfish and mosquito fish, the bottom layer was clear and supported shrimp and blind cave fish. Sunlight was absent at the bottom and in the brackish strata. These intermediate layers, generally brownish in divers' lights and in samples, have remarkable concentrations of $\mathrm{H}_{2} \mathrm{~S}$, which increase with depth to if more than $25 \mathrm{mg}$ per litre, the $\sum$ limit of the test equipment.

The luckless divers in this well found that their chromium$\checkmark$ plated equipment turned black, they felt nauseated, and their exposed skin felt burned. They were understandably surprised to discover that the water contained living larvae of the phantom midge, evidently a creature made of sterner stuff. The cause of the hostile conditions seems to be a filamentous sulphatereducing bacterium, probably a species of Desulfovibro, which drapes the rocks and underground tree limbs there in a thick white coating.

ground water. Their presence in limestone aquifers can be diagnosed from characteristic concentrations of hydrogen, an intermediate in the redox reac. tion, and detectable by gas chromatogra. phy (D. Lovley, US Geological Survey).

Natural limestone wells in coastal areas sometimes also show evidence of sulphur activity, resulting there from the interaction of sulphate-bearing sea water with infalls of forest litter. For instance, the northern Bahamas show a zone where organic material becomes neutrally buoyant at the interface between fresh water above and denser salt water below (F. Whitaker, Univ. of Bristol). This promotes the growth of sulphatereducing bacteria and causes a solutional nip to cut into the limestone.

An even more dramatic case occurs at a natural well, Conote Verde, $4 \mathrm{~km}$ inland from the coast of Yucatan (W. Wilson, Karst Environmental Services, Florida). When the well was visited by divers in the autumn, the water was stratified: fresh in the top $8 \mathrm{~m}$, salt below a depth of $30 \mathrm{~m}$, and with various brackish concentrations in between. The top layer was a
The dissolution of limestone to produce most caves results from carbonic acid derived from soil gases. But some of the world's largest caves are believed to have been formed by sulphuric acid resulting from the action of sulphur bacteria. At Carlsbad Caverns National Park, it seems that $\mathrm{H}_{2} \mathrm{~S}$ from the oil fields of West Texas migrated northwards and upwards to form sulphuric acid that etched out the caves (C. Hill, Hi Tech, Albuquerque).

In the same park, recent exploration of the great Lechiguilla cave has expanded its known size and revealed decorations of exquisite beauty (K. Cunningham, US Geological Survey), many of which owe their origin to formerly nauseating processes mediated by sulphur bacteria. Deposits of native sulphur, so massive they are measured in tonnes, remain in the cave today as clear evidence of the former activity of the bacteria.

George W. Moore

George W. Moore is in the Department of Geosciences, Oregon State University, Corvallis, Oregon 97331, USA. 